\title{
神奈川県逗子海岸の海浜変形と養浜の効果検討 BEACH CHANGES OF ZUSHI COAST IN KANAGAWA PREFECTURE AND EFFECT OF BEACH NOURISHMENT
}

\author{
宇多高明 1 - 渡辺宗介 ${ }^{2} \cdot$ 細川順一 2 - 塩入 同 ${ }^{3} \cdot$ 三波俊郎 4 - 石川仁憲 5 \\ Takaaki UDA, Shusuke WATANABE, Jun-ichi HOSOKAWA, \\ Dou SHIOIRI, Toshiro SAN-NAMI and Toshinori ISHIKAWA \\ 1正会員 工博 (財) 土木研究センター常務理事なぎさ総合研究室長兼日本大学客員教授 \\ 理工学部海洋建築工学科（†110-0016 東京都台東区台東1-6-4タカラビル） \\ 2海岸研究室（有）（†160-0011 東京都新宿区若葉1-22 ローヤル若葉301） \\ 3 神奈川県県土整備局河川下水道部流域海岸企画課（（２31-8588 神奈川県横浜市中区日本大通1） \\ 4神奈川県藤沢土木事務所なぎさ河川砂防部なぎさ港湾課（†253-0033 神奈川県茅ヶ崎市汐見台1-7）

\section{5 正会員 工修 (財) 土木研究センターなぎさ総合研究室} \\ （干110-0016 東京都台東区台東1-6-4タカラビル）
}

\begin{abstract}
The effect of beach nourishment on the Zushi coast was predicted using the BG model proposed by Serizawa et al. Because southward longshore sand transport was induced by the wave sheltering effect of the breakwater of Hayama New Port, sand back pass at a rate of $500 \mathrm{~m}^{3} / \mathrm{yr}$ from the sand deposition zone immediately in front of the Tagoshi River mouth is required to maintain the beach. To widen the beach width in the central part of the coast, beach nourishment at a rate of over $500 \mathrm{~m}^{3} / \mathrm{yr}$ is required. To recover the shoreline before the construction of the port, 2000 $\mathrm{m}^{3} / \mathrm{yr}$ of sand nourishment is needed.
\end{abstract}

Key Words : Zushi coast, beach nourishment, wave sheltering effect, BG model

\section{1. まえがき}

三浦半島西岸は多くの岬と入江を有する複雑な形 状の海岸線からなり, 沿岸には数多くのポケット ビーチが発達している（図-1）。これらのポケット ビーチは長い間安定であったが，近年いくつかのポ ケットビーチでは侵食が進んでいる ${ }^{1 ）}{ }^{2)}$. 三浦半島 基部に位置する逗子海岸では，ポケットビーチ南端 沖に葉山港の防波堤が伸ばされた後, 南寄りの入射 波が防波堤により遮蔽された結果, 遮蔽域一向から 沿岸漂砂が誘起され，これにより北部汀線は後退し， 逆に南部では砂が堆積して汀線が前進するという変 化が起きた。結果的に中央から北部の前浜は狭まり， 満潮時には背後の道路護岸へ波が直接作用する状況 となった。このため前浜が狭まった逗子海岸北部で は，2004年から試験養浜が始められた。当初は現地 砂 (中央粒径 $d_{50}=0.28 \mathrm{~mm}$ の細砂) と同じ粒径の砂が 投入されたが，2009年には $d_{50}=1.05 \mathrm{~mm}$ の粗砂 $500 \mathrm{~m}^{3}$ を 用いた試験養浜も行われ，養浜前後の汀線測量デー タなどに基づいて投入土砂の挙動が調べられた。こ のように養浜は行われてはいるものの，長期的に見 た養浜の効果の定量予測は行われていなかった。そ こで本研究では, 細砂や粗砂養浜を継続的に行った

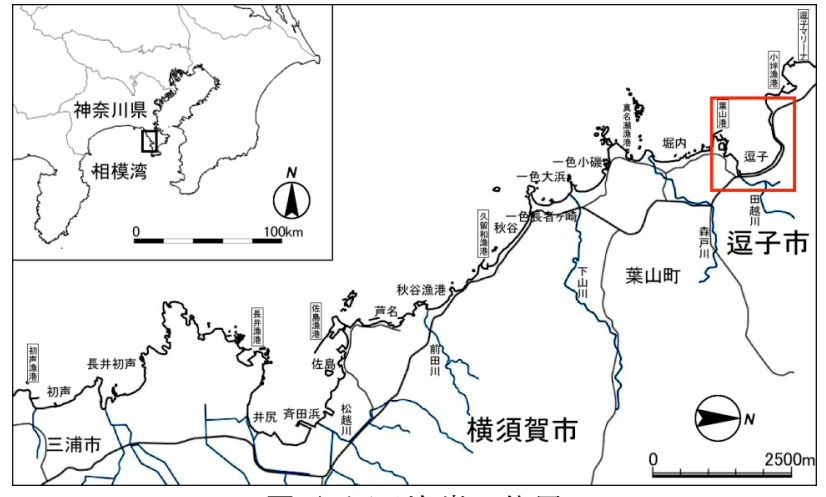

図-1 逗子海岸の位置

場合の効果についてBGモデル（Bagnold概念に基づ く海浜変形モデル） ${ }^{3)}$ を用いて検討した.

\section{2. 逗子海岸の海浜変形の実態}

逗子海岸は両側を岩盤に挟まれた奥深いポケット ビーチであり，その長さは約 $1.1 \mathrm{~km}$ であ。図-2は 2009年撮影の逗子海岸の空中写真を示す. ポケット ビーチの南端には田越川が岬の陰に隠れるようにし て流入し, 河口沖には下水処理場の埋立地と, さら 


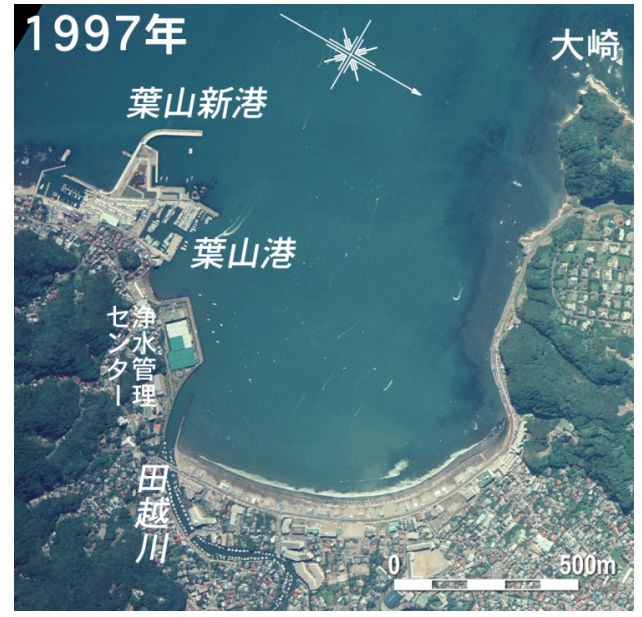

図-2 逗子海岸の空中写真

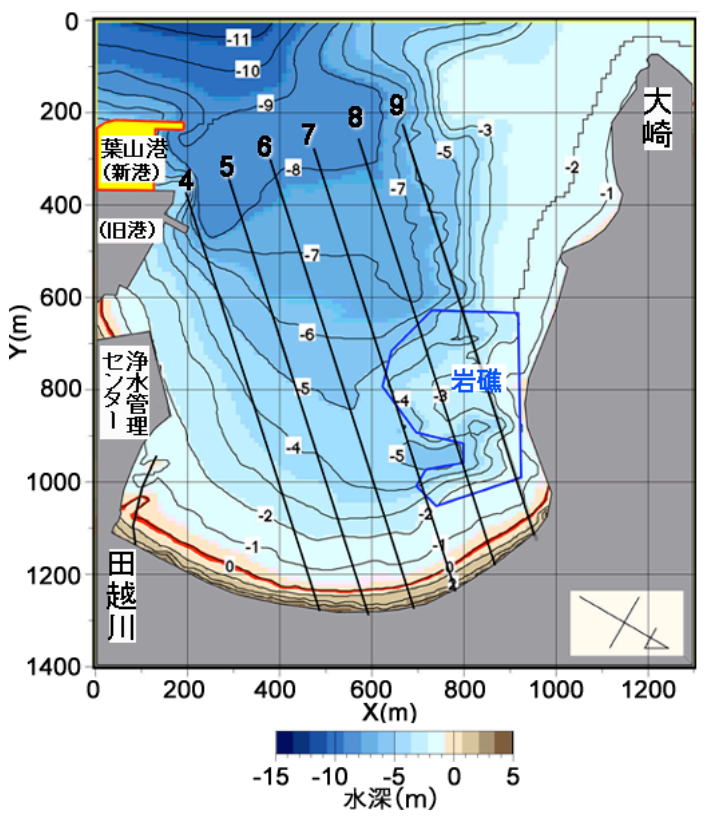

図-3 深浅図 (2009年1月)

にその沖には葉山港の防波堤が伸びている。また， ポケットビーチ北部から大崎にかけて沖には岩礁帯 が広がっていることが黒い海底面状況から見て取れ る。この岩礁帯の陸側では緩やかに突出した舌状砂 州が見られることから，岩礁による波の遮蔽効果が 発揮されていることが分かる。図-3は2009年の深浅 図を示す。北部には陸から続く岩盤が沖合 $500 \mathrm{~m}$ 付近 まで張り出しており，この岩礁にはカジメ・ガラモ などの海藻類が繁茂し, 魚介類の産卵・生息場と なっている。

逗子海岸の 1954～2005 年の汀線変化については, 既に明らかにされている1）2）4）ので省略し，1997年 基準での2004，2009年までの汀線変化を図-4に示す. 葉山港の防波堤建設に伴う波の遮蔽域形成により， 長期的には $X=0.6 \mathrm{~km}$ より北側では汀線が後退, 南側 では前進してきた。北側の侵食に対して 2004 年3月 に $1,540 \mathrm{~m}^{3}$ の養浜が行われ，その後毎年 $500 \sim 700 \mathrm{~m}^{3}$ の 養浜を継続し，2009年3月までに計 $4,650 \mathrm{~m}^{3}$ の砂が投 入された。 2008 年 3 月までの養浜材は, 現地砂と同 じ粒径の細砂（ $d_{50}=0.28 \mathrm{~mm} ）$ であったが，2009年3月

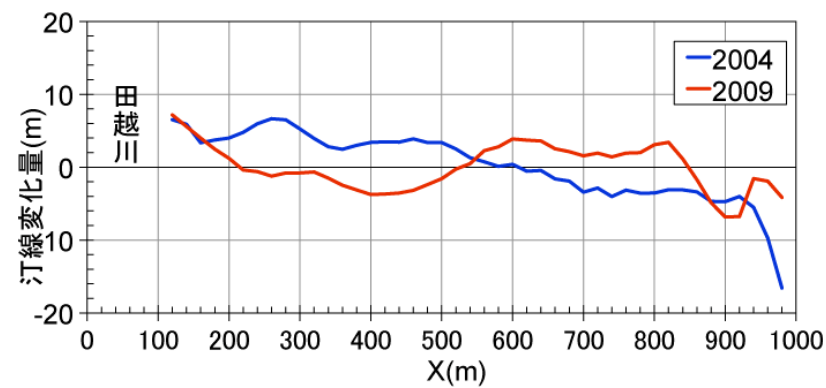

図-4 汀線変化（1997年基準）

には $d_{50}=1.05 \mathrm{~mm}$ の粗砂 $500 \mathrm{~m}^{3}$ が投入された。図-4には 養浜後の 2009 年までの汀線変化も示すが，北部では 汀線の前進が認められる。これには養浜による効果 も考えられるが，北部のみの局所的な汀線の前進で はなく，中央〜南部では侵食傾向にあることから一 時的な南寄りの波の入射による汀線変化も重なって いると考えられる。

逗子海岸では図-3に示すように沿岸方向に $100 \mathrm{~m}$ 間 隔の9測線に沿って1988年以降縦断測量が行われて きた。測量データのうち，測線No. 4〜No. 9の縦断形 変化を図-5に示す。これらによれば，バーム高 $h_{R}$ は 2.5〜3mにあり，主な縦断形変化は，南部ではほぼ$4 \mathrm{~m}$ 以浅で, また北部では- $2 \mathrm{~m}$ 以浅で起きている。こ れらより当海岸における波による地形変化の限界水 深 $h_{c}$ は-3m付近にあると推定される.

\section{BGモデルによる海浜変形予測}

\section{（1）計算条件}

逗子海岸では，葉山港（新港）建設以前（1997 年）の海底地形データがないことから，まず2009年 の海底地形条件のもとで葉山港（新港）の施設を取 り除き，防波堤がない状態で安定な海浜が得られる まで十分長い時間（30年）波を作用させて1997年当 時の海浜形状を再現した。波浪場の計算には不規則 波の方向分散法 ${ }^{5)}$ を用い, 逗子海岸におけるエネル ギー平均波（波高 $H=0.7 \mathrm{~m}$ ，周期 $T=7.0 \mathrm{~s}$ ）を与えた. また波向については試行錯誤方式で検討したところ, 海浜形状を最もうまく再現できる波向は $-7^{\circ}$

（S67W）であった。逗子海岸では北部に広い岩礁 帯があるが，波浪場の計算では，試行計算によりこ れらの岩礁带の透過率は 0.4 とした。また地形変化 の計算では，この岩礁帯は露岩として扱った。一連 の試行錯誤方式での検討により，少なくとも実測の 海底地形を実用上十分な精度で再現可能となった。

次に，1997年の再現地形を初期条件として1997〜 2009年の地形変化を計算し, さらに2009年地形を与 えて10年後の予測を行った。予測計算では, 養浜を 行わずにそのまま放置する案を基礎として, 細砂・ 粗砂による養浜を $500 \mathrm{~m}^{3} / \mathrm{yr}$ で行う案や, 細砂養浜を $2000 \mathrm{~m}^{3} / \mathrm{yr}$ で海浜北端部や海浜中央部で行う案など の検討を行い，相互比較を行った．表-1には計算条 件を示す. 

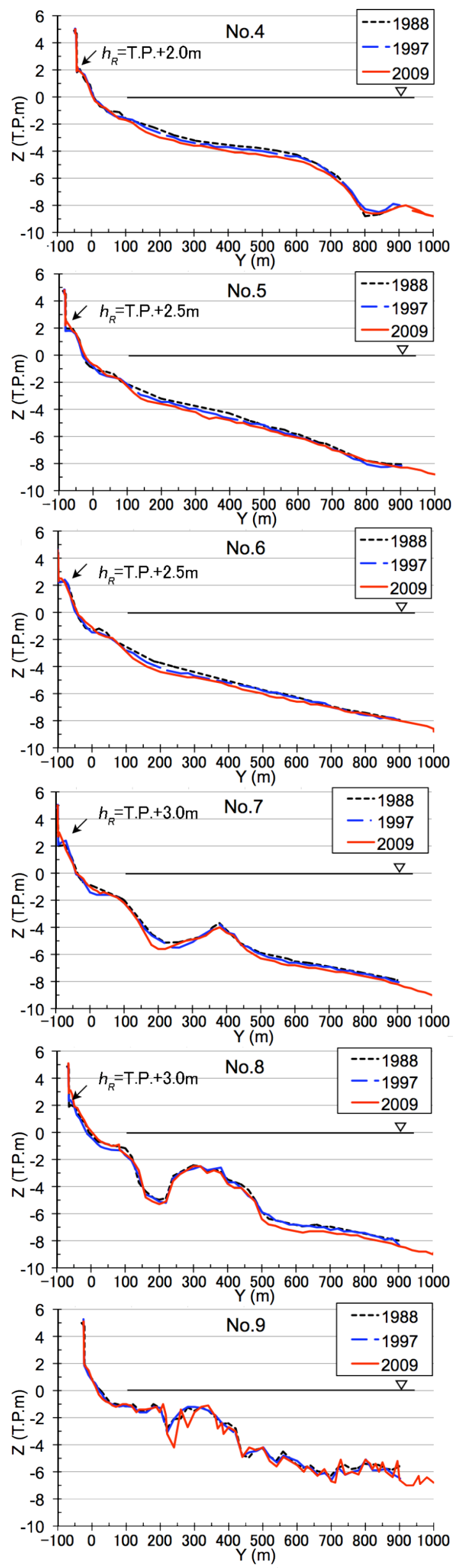

図-5 縦断形変化
表-1 計算条件

\begin{tabular}{|c|c|}
\hline 計算モデル & $\begin{array}{l}\text { 粒径BGモデル }{ }^{3)} \\
\text { 波浪場の計算：方向分散法 }{ }^{5)}\end{array}$ \\
\hline 計算対象区域 & $\begin{array}{l}\text { 波浪・地形変化計算：沿岸方向 } \\
1.3 \mathrm{~km} \times \text { 岸沖方向 } 1.4 \mathrm{~km}\end{array}$ \\
\hline 初期地形 & $\begin{array}{l}\text { 1997年再現：2009年の実測海底地 } \\
\text { 形で葉山港の施設を除去 } \\
\text { 2009年再現：1997年再現計算で得 } \\
\text { られた安定形 } \\
\text { 将来予測 : } 2009 \text { 年再現計算 }\end{array}$ \\
\hline 計算ケース & 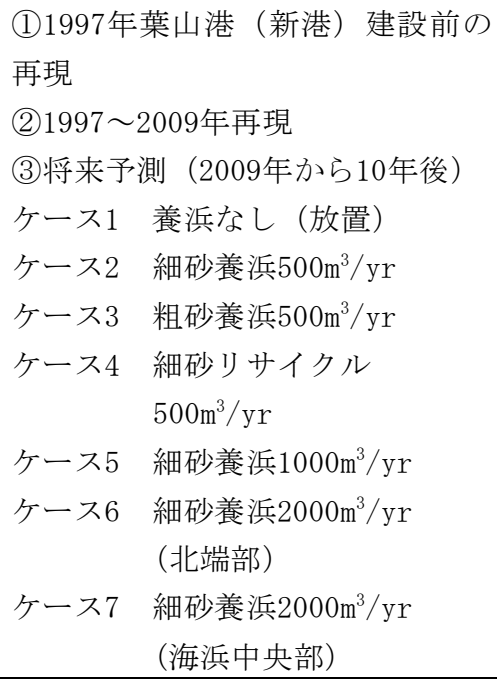 \\
\hline 計算期間 & $\begin{array}{l}\text { (1) } 1997 \text { 年再現 : 安定化するまで十 } \\
\text { 分波浪を作用（30年） } \\
\text { (2) } 1997 〜 2009 \text { 年再現 : 12年 } \\
\text { (3)ケース } 1 \text { ケ : 10年 }\end{array}$ \\
\hline 入射波条件 & $\begin{array}{l}\text { 波高 } H=0.7 \mathrm{~m}, \text { 周期 } T=7.0 \mathrm{~s} （ \text { 逗子海 } \\
\text { 岸におけるエネルギー平均波） } \\
\text { 波向 }-7^{\circ} \quad\left(\mathrm{S} 67^{\circ} \mathrm{W}\right) \quad(\text { 再現の試行計 } \\
\text { 算より決定 }) \\
\text { 方向分散性 : } S_{\max }=10\end{array}$ \\
\hline 潮位条件 & M. S. L. $\pm 0.0 \mathrm{~m}$ \\
\hline $\begin{array}{l}\text { 計 算 空 間 メッ } \\
\text { シュ }\end{array}$ & $\Delta \mathrm{X}=10 \mathrm{~m}$ \\
\hline 計算時間間隔 $\Delta t$ & $\Delta t=2 \mathrm{hr} / \mathrm{step}$ \\
\hline 計算ステップ数 & 4380 step/yr \\
\hline $\begin{array}{l}\text { 漂砂の水深方向 } \\
\text { 分布 }\end{array}$ & 一様分布 \\
\hline $\begin{array}{l}\text { 波による地形変 } \\
\text { 化の限界水深 }\end{array}$ & $h_{c}=3 \mathrm{~m}$ \\
\hline バーム高 & $h_{R}=3 \mathrm{~m}$ \\
\hline
\end{tabular}

\section{（2）計算条件}

図-6 (a) は不規則波の方向分散法で求めた $\mathrm{Kr} の$ 分 布を，図-6(b) は図-6(a)の波高分布を与えて求めた 1997年当時の安定海浜形状を示寸. 当時葉山港（旧 港）のみが存在したが，これによる波の遮蔽効果が 現れ，田越川河口部は静穏な条件にあった。一方， 北側にある水深 $3 \mathrm{~m}$ 程度の岩礁による遮蔽効果のため 
(a) $\mathrm{Kr}$ の分布

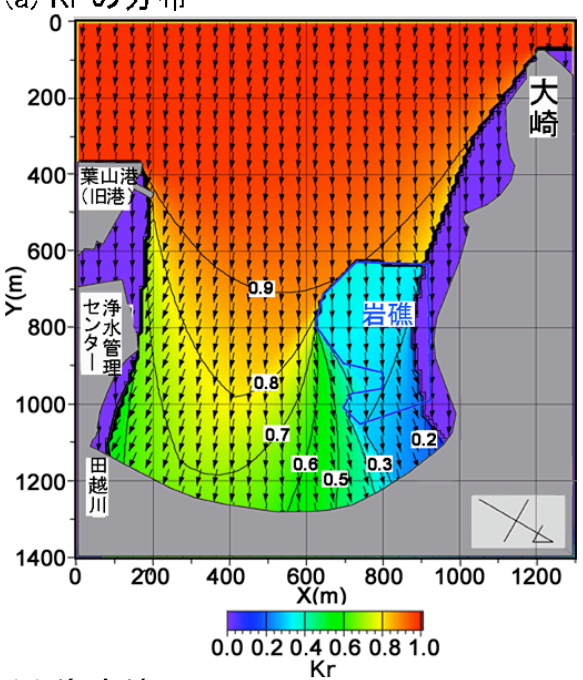

(b) 海底地形

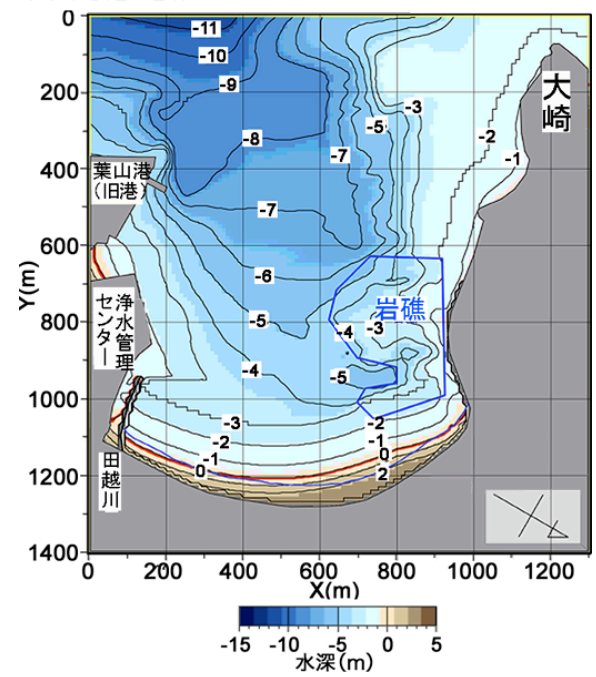

図-6 1997年当時の地形条件で求めた Krの分布と 再現された1997年地形

に，その背後に静穏域が広がっていた。この静穏域 の背後では緩やかな舌状砂州が形成されていた。

次に, 図-6(b) の海底地形を与えるとともに葉山 港（新港）を設置し方向分散法で求めた $K r$ の分布と, 2009年の予測地形を図-7 (a) (b) に示す。葉山港（新 港）がポケットビーチの南端に突出したことにより， 南端部で波の静穏度が上昇した。図-8には1997〜 2009年の地形変化量を示寸. 岩礁背後が侵食され, 最大 $0.5 \mathrm{~m}$ 海浜地盤高の低下が起こる一方, 砂が南向 きに運ばれ, 田越川河口導流堤の隣接域で堆積した ことが分かる。これは葉山港（新港）が岬の南端に 設置されたことにより, ポケットビーチの南側半分 での波の遮蔽効果が高まったことによる地形変化で ある。

図-9には計算と実測の汀線変化の比較を示す. 2004年の再現計算結果は, 北側の汀線後退量, 南側 の汀線前進量, $X=600 \mathrm{~m}$ を節とした汀線変化をほぼ再 現できている。.また実測では南寄りの波による反時 計回りの一時的な地形変化が生じていたが，2009年 までの計算結果によれば北側でさらに侵食が進むこ とが分かる。したがって, 将来予測計算では危険側
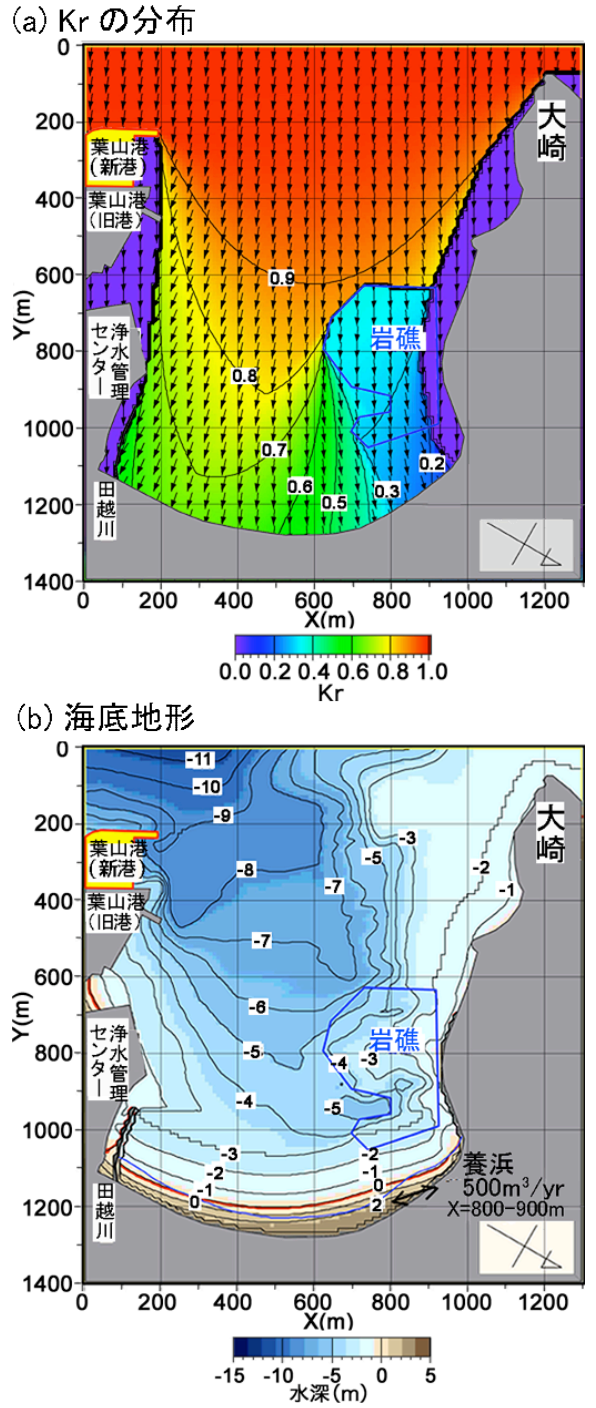

図-7 2009年の地形条件で求めた $\mathrm{Kr}$ の分布と 再現された2009年地形

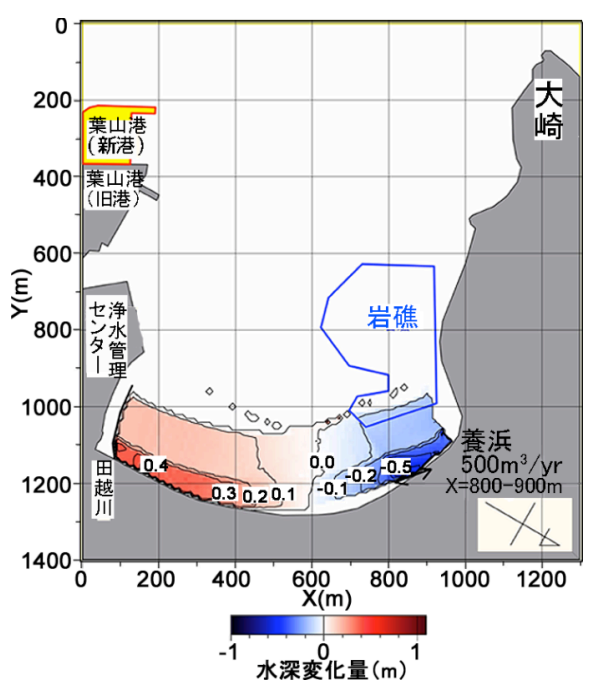

図-8 1997年から2009年までの 水深変化量

の検討として2009年の計算結果を初期地形として与 えた。 


\section{（3）将来予測計算の結果}

将来予測計算は 2009 年を初期として 10 年後まで行 い, 養浜砂の粒径と養浜量を種々変えて計算を行っ た. 図-10は，ケース1 (放置) の水深変化量の分布 を示す. 1997～2005年の地形変化（図-8） と同様， ポケットビーチの岩礁背後での侵食が継続し, 砂が 南側へと運ばれる。これより現況のまま放置するこ とはできないことが明らかである。そこで養浜の効 果を調べた。図-11, 12 は, 養浜量 $500 \mathrm{~m}^{3} / \mathrm{yr}$ で細 砂・粗砂養浜を行うケース 2,3 の地形変化量分布を 示す．ケース1の結果（図-10）と比較すると，いず れの場合も岩礁背後での侵食が軽減されることから 養浜効果が認められるが, 粗砂養浜の場合歩留まり が高いという結果となった。

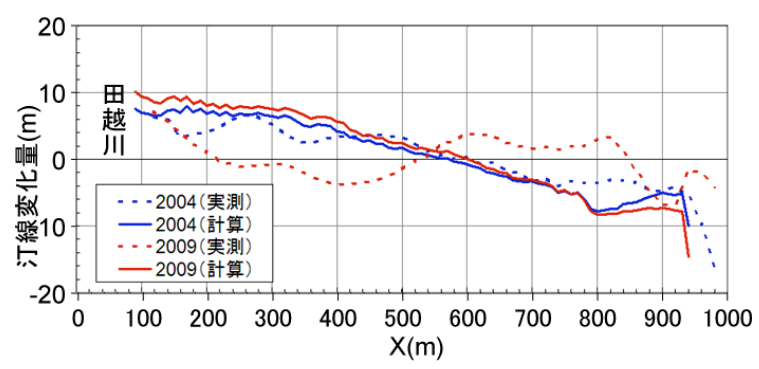

図-9 計算と実測汀線変化量の比較

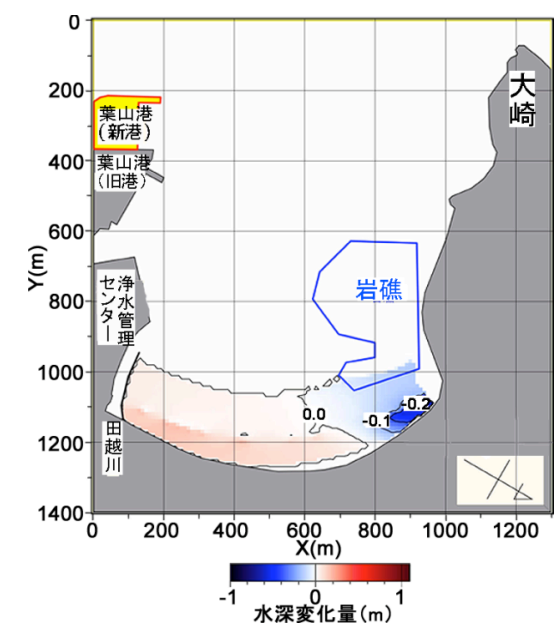

図-10 水深変化量（ケース1：放置）

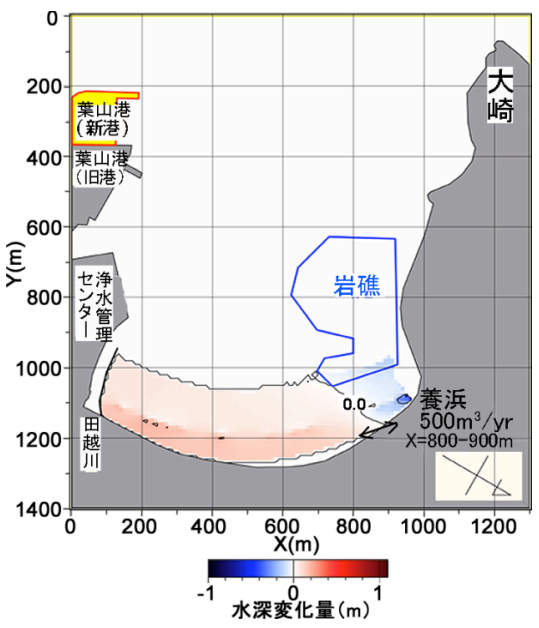

図-11 水深変化量（ケース $2: 500 \mathrm{~m}^{3} / \mathrm{yr}$ の細砂養浜）
養浜量を $500 \mathrm{~m}^{3} / \mathrm{yr}$ としたまま, 養浜土砂を田越川 の右岸側から調達するサンドリサイクルを行うケー ス4では，図-11に示したケース 2 の細砂養浜時にお ける岩礁背後での侵食域の分布とほぼ同様な結果と なるが，新たに砂の採取を行う田越川河口右岸で凹 の䆶みができる（図-13）。図-14，15は，養浜量を $1000 \mathrm{~m}^{3} / \mathrm{yr}, 2000 \mathrm{~m}^{3} / \mathrm{yr}$ と増大させた場合の計算結果 （ケース5，6）を示す. 養浜量が増加したため海浜 北端部の岩礁背後で著しい堆積が生じる結果となる. さらに養浜箇所をポケットビーチ中央部に変えて $2000 \mathrm{~m}^{3} / \mathrm{yr}$ の養浜を行った場合の計算結果（ケース 7）を図-16に示寸。この条件では，侵食が進んでき た北端部の侵食は止められず, 海浜中央部での堆積 量が増すので採用しにくい.

各ケースの計算結果より, 2009年より10年後の汀 線変化を抽出し, 相互比較を行ったのが図-17,18で ある. 放置案では海浜の北端部で約 $5 \mathrm{~m}$ の汀線後退が 起こり，侵食土砂が南向きの沿岸漂砂によって運ば れ, $X=700 \mathrm{~m}$ 以南の広い区域で堆積する。 これに対し $\tau 500 \mathrm{~m}^{3} / \mathrm{yr}$ の養浜を行うケース 2 (細砂)，ケース 3

（粗砂）では侵食量が減少し, 侵食域も大きく狭ま ることから $500 \mathrm{~m}^{3} / \mathrm{yr}$ の養浜でも有効なことが分かる. 一方, 田越川河口右岸で $500 \mathrm{~m}^{3} / \mathrm{yr}$ の割合で砂の採取 を行うサンドリサイクルでは, 海浜南部の汀線は前

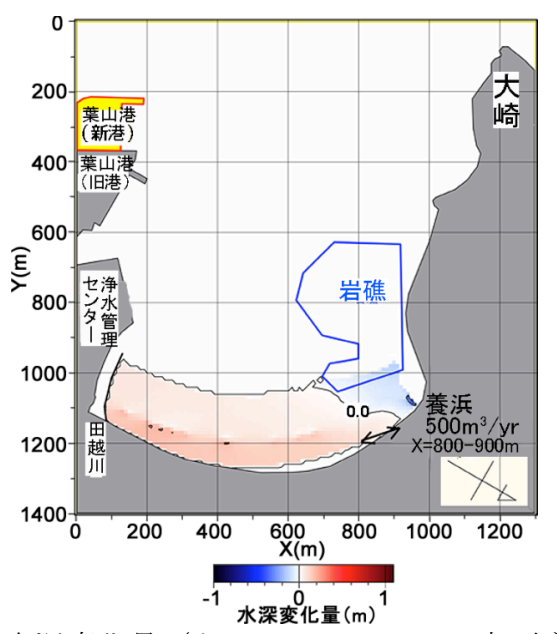

図-12 水深変化量（ケース $3: 500 \mathrm{~m}^{3} / \mathrm{yr}$ の粗砂養浜）

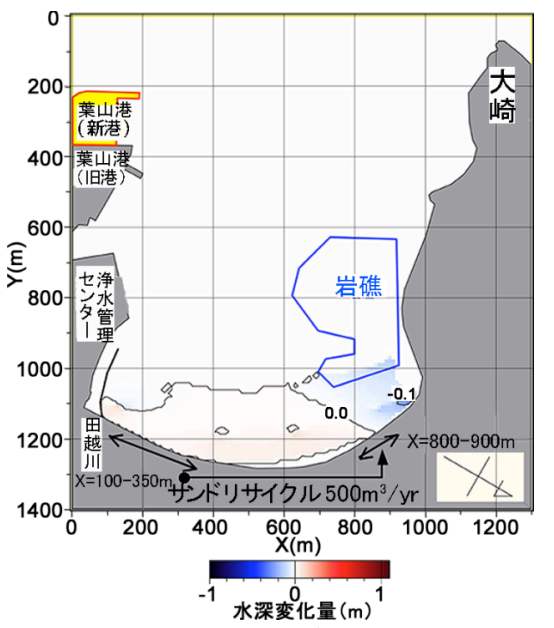

図-13 水深変化量

(ケース $4: 500 \mathrm{~m}^{3} / \mathrm{yr}$ のサンドリサイクル) 


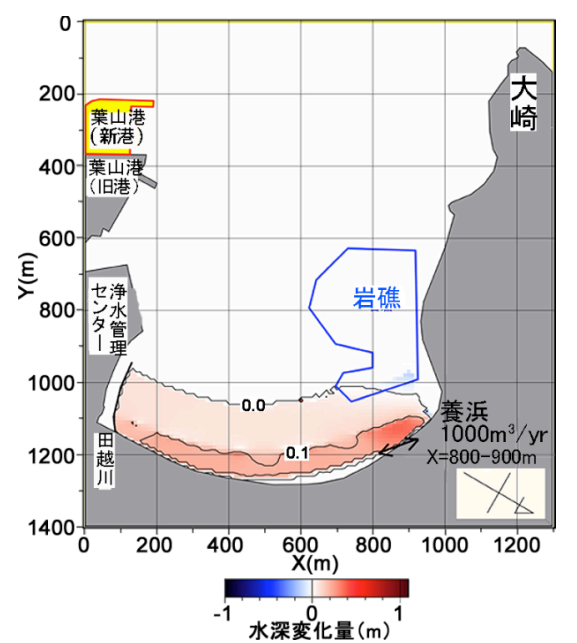

図-14 水深変化量（ケース $5: 1000 \mathrm{~m}^{3} / \mathrm{yr}$ の細砂養浜）

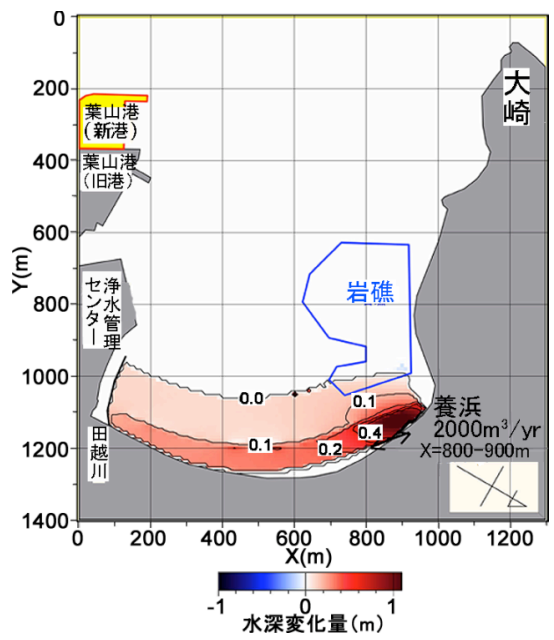

図-15 水深変化量

(ケース6: $2000 \mathrm{~m}^{3} / \mathrm{yr}$ の細砂養浜：北端部)

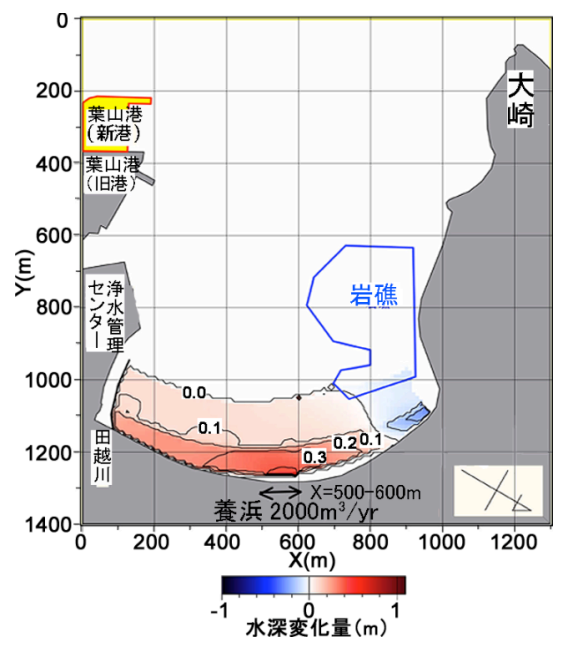

図-16 水深変化量

(ケース 7: $2000 \mathrm{~m}^{3} / \mathrm{yr}$ の細砂養浜：中央部)

進せず，一定量の砂が南向きに流れるのみとなる.

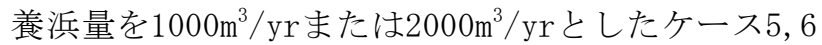
では, 著しい汀線前進効果が得られる。しかし $2000 \mathrm{~m}^{3} / \mathrm{yr}$ の養浜を海浜の中央で行うケース7では, 中央部での浜幅の拡幅には有効であるが，北端部の 従来から侵食されてきた場所では侵食が止まらない。 このことから同じ $2000 \mathrm{~m}^{3} / \mathrm{yr}$ の養浜であっても海浜

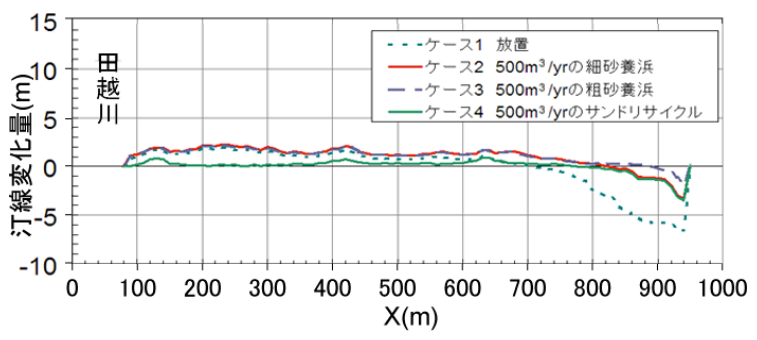

図-17 汀線変化比較（ケース $1,2,3,4 ）$

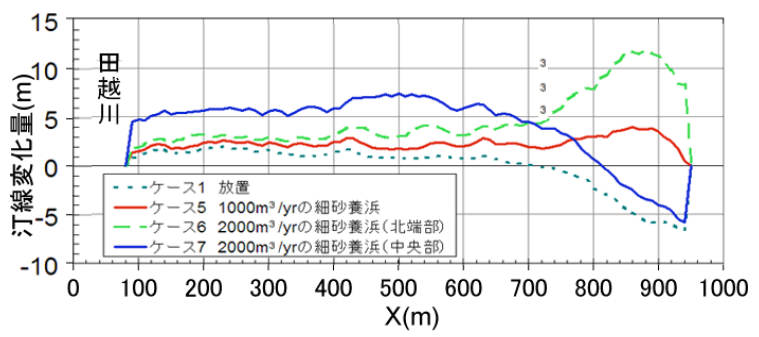

図-18 汀線変化比較（ケース $1,5,6,7 ）$

中央部での養浜は北端部での養浜と比べて劣ると言 える.

\section{4.まとめ}

逗子海岸を対象にBGモデルを用いて養浜の効果検 討を行った。この結果, 葉山新港による波の遮蔽効 果に起因する南向きの沿岸漂砂が続くために, 南端 の田越川河口への堆砂の防止を図りつつ海浜を維持 するには，南端部から北端部への $500 \mathrm{~m}^{3} / \mathrm{yr}$ のサンド リサイクルが必要である。また中央部の浜幅の狭い 場所を広げるには北端部で $500 \mathrm{~m}^{3} / \mathrm{yr}$ 以上の養浜を行 えばよく，その場合投入砂の粒径が大きなほど汀線 への歩留まりが高まる。 さらに葉山港（新港）の建 設前の汀線の回復を目指すには $2000 \mathrm{~m}^{3} / \mathrm{yr}$ の養浜が 必要なことが分かった。

\section{参考文献}

1) 宇多高明, 高村光雄, 藤元和雄, 中西史一, 壱岐信二, 石川仁憲 : 三浦半島西岸の小規模なポケットビーチで の海浜変形の実態, 海岸工学論文集, 第 55 巻, pp. 711-715, 2008.

2) Uda, T., M. Takamura, K. Fujimoto, F. Nakanishi, S. Iki and T. Ishikawa: Shoreline rotation on pocket beaches caused by anthropogenic factors, Proc. Coastal Dynamics 2009, paper No. 70, pp. 1-11, 2009.

3) 芹沢真澄, 宇多高明, 熊田貴之, 三波俊郎, 古池 鋼, 石川仁憲, 野志保仁 : Bagnold 概念に基づく混合粒径 海浜の変化予測モデル, 海岸工学論文集, 第 53 巻, pp. 626-630, 2006.

4) 宇多高明, 小林正博, 村上義隆, 三澤 舞, 壱岐信 二: 神奈川県逗子海岸における試験養浜の追跡調査, 海洋開発論文集, 第 26 巻, pp. 1059-1064, 2010.

5) 酒井和也, 小林昭男, 宇多高明, 芹沢真澄, 熊田貴 之: 波の遮蔽構造物を有する海岸における 3 次元静的 安定海浜形状の簡易予測モデル, 海岸工学論文集, 第 50 巻, pp. 496-500, 2003. 